\title{
The impact of urban conditions on different tree species in public green areas in the city of Poznan
}

\author{
Michał Krzyżaniak*, Dariusz Świerk, Miłosz Walerzak, Piotr Urbański \\ Department of Landscape Architecture \\ Poznan University of Life Sciences \\ Dąbrowskiego 159, 60-594 Poznań, Poland
}

\begin{abstract}
Parks in urbanised areas fulfil an important function as they create a positive climate in cities and contribute to the good health of their inhabitants. The study gives an answer to the question of which of the species under investigation is the most suitable for planting in urbanised areas. The aim of the research conducted from 2013 to 2014 at selected sites in Poznan (Poland) was to determine the state of health of Tilia cordata Mill., Acer platanoides L. and Quercus robur L. trees and to compare their state of health depending on the location of the research sites. The aim of the research was also to determine the environmental variables that may have an influence on the state of health of the tree species under analysis. The research included statistical analyses and models based on discriminant analysis. The research revealed that the state of health of the tree species under investigation growing in the city is determined by anthropogenic factors. The closeness of the city centre, main thoroughfares and estates heated with fossil fuels are the factors that have the most negative influence on the state of health of oak, maple and lime trees. Acer platanoides L. was the species in the best state of health in parks, whereas in forests it was Tilia cordata Mill.
\end{abstract}

Key words: Norway maple, pedunculate oak, small-leaved lime, statistical models, urbanised areas

\section{INTRODUCTION}

The air quality in urbanised areas is a serious problem in view of the expansion of both urban and industrial zones (Kanakidou et al. 2011). Soil moisture, the content of nutrients, weather extremes, pathogens and pests have been found to exert influence on the processes related with progressing defoliation of tree crowns in public open spaces. The sites of woody vegetation have been proven to have a considerable influence on the accumulation and retention of water and on the supply of groundwater (Millward and Sabir 2011). Physiochemical investigations are commonly applied methods to monitor the quality and cleanness of air in urbanised areas.
However, such investigations are very expensive and complicated. Therefore, they are not made in the entire area of the city but they are only limited to several locations. Apart from that, most often such investigations are related to the concentration of only a few types of pollutants (e.g. $\left.\mathrm{NO}_{x}, \mathrm{SO}_{2}, \mathrm{O}_{3}\right)$, but they do not provide direct evidence for the influence of changes in the quality and cleanness of air in urbanised areas on the state of health and vegetation of plants (Honour et al. 2009). Studies conducted in different cities in the United States have proved that trees growing in urbanised areas may reduce pollution consisting of ozone, suspended particulate matter, sulphur dioxide, carbon monoxide and 
nitrogen oxides (Paoletti et al. 2011, Baumgardner et al. 2012, Schnell et al. 2012).

Small-leaved lime, Norway maple and pedunculate oak trees are species that can most often be found in public open spaces (both in parks and municipal forests). Tilia cordata Mill. trees prefer moist, permeable and fertile soils and they exhibit tolerance to the presence of calcium in the soil. The trees of the Tilia genus are also relatively resistant to drought - they are more resistant than the trees of the Betula, Alnus or Carpinus genera, but they are less resistant than the trees of the Fraxinus, Quercus or Sorbus genera (Bassuk et al. 2009, Roloff et al. 2009). Acer platanoides L. is a lowland species that can mainly be found in deciduous and mixed forests, especially on nutrientrich and sufficiently moist soils (Boratynski 1999). Experiments have proven that Acer platanoides L. trees can cope with water deficit and stress related with this deficit better than Populus tremula L., Quercus robur L. and Tilia cordata Mill. trees (Aasamaa and Sõber 2001). Acer platanoides L. trees can be classified as more resistant to drought than Aesculus hippocastanum L. trees (Roloff et al. 2009). Pedunculate oak trees have been found to exhibit tolerance to the changing warming climate. Therefore, their share in tree-covered areas in Central Europe will be increasing (Saha et al. 2012).

The trees of the Tilia genus should be grown among the tall greenery of housing estates, parks and other urbanised areas. However, it is not recommended to plant them in streets and squares because of difficult environmental conditions and high pollution with copper, zinc and lead compounds, which are chiefly emitted by different means of transport. The trees of the Tilia genus may be applied more widely in areas outside cities, especially as roadside trees forming avenues (Hovmand et al. 2009, Sjöman and Busse 2010). Other studies on Quercus robur L. trees prove that specimens of this species acidify the soil within the rhizosphere and thus they reduce the concentration of heavy metals in shallower soil layers (Mertens et al. 2007). Barzdajn (2006) notes that at present Quercus robur L. trees are of minor importance in tree-covered areas in cities and estates. This situation is caused by the fact that there is minimal production of the species in nurseries and these trees do not tolerate replanting at an older age. The same author also notes that the species is not sufficiently used in parks, although it is resistant to drought, air pollution and considerably tolerant to soil conditions. Acer platanoides L. trees are often planted in Polish urban and manorial parks. In open landscapes they are used to make buffer groups and strips and they are planted as roadside trees (Bojarczuk 1999). The trees of this species are also appreciated on the North American continent because of their advantages, i.e. resistance to air pollution, resistance to soil compaction, rapid growth and high resistance to shading (Millward and Sabir 2011).

Increased concentrations of $\mathrm{Na}, \mathrm{Cl}, \mathrm{Ca}, \mathrm{Mg}$, $\mathrm{Zn}$ and $\mathrm{Cu}$ and increased soil $\mathrm{pH}$ have a negative influence on the state of health of small-leaved lime trees growing near main thoroughfares. Also, increased salinity or EC caused by increased levels of $\mathrm{Na}$ and $\mathrm{Cl}$ do not have a favourable influence on Tilia cordata Mill. trees, causing the phenomenon of physiological drought, especially in the spring (Bassuk et al. 2009, Cekstere and Osvalde 2013). Salinity is one of the main hazards to Acer platanoides L. trees in urbanised areas. Experiments have proved that Norway maple trees are a species of medium sensitivity to salinity, because they are more sensitive to salinity than Acer campestre L. trees but they are more tolerant than Acer pseudoplatanus L. trees (Bojarczuk 1999).

Studies have proven that deciduous trees are more sensitive to exposure to $\mathrm{O}_{3}$ and its effect, whereas coniferous trees are more sensitive to high concentrations of $\mathrm{SO}_{2}$ and $\mathrm{NO}_{2}$ in the air (Paoletti et al. 2011). The trees of the species under investigation are also relatively resistant to air pollution in urbanised areas. Aesculus hippocastanum L. trees are characterised by higher seasonal accumulation of $\mathrm{Cr}, \mathrm{Fe}, \mathrm{Ni}$ and $\mathrm{Pb}$ ions in foliage than Tilia cordata Mill. trees. Also, Tilia cordata Mill. trees have not been found to accumulate $\mathrm{Cu}$ ions in their foliage. However, Tilia cordata Mill. trees are less resistant to the air pollution in urbanised areas than the trees of the Carpinus and Robinia genera (Aničić et al. 2011). Tilia cordata Mill. trees have also been found to be much less sensitive to the air pollution with nitrogen than Salix alba L., Tilia platyphyllos Scop. or Fraxinus excelsior L. trees (Novak et al. 2003). Pedunculate oak trees are very or relatively resistant to the effect of $\mathrm{SO}_{2}$. The species tolerates the influence of oxidising gases $\left(\mathrm{O}_{3}, \mathrm{PAN}, \mathrm{NO}_{\mathrm{x}}\right)$, acidic gases $\left(\mathrm{SO}_{2}\right)$ and alkaline gases $\left(\mathrm{NH}_{3}\right)$ and it is relatively resistant to the influence of fluorine compounds (Barzdajn 2006). However, researchers note that individual older oak trees may die when their defoliation does not exceed 20\% (Eichhorn and Paar 2000). It is noteworthy that oak trees that 
are devoid of more than $60 \%$ of their assimilation apparatus usually die within a few years, whereas specimens of the species that have suffered less damage survive and often regenerate (Sonesson 1999). Canadian studies in 2008 proved that Norway maple trees have the greatest share in reduction of the $\mathrm{CO}_{2}$ level and are also responsible for the reduction of such pollutants as $\mathrm{O}_{3}, \mathrm{NO}_{2}$ and $\mathrm{SO}_{2}$ and the reduction of suspended particulate matter in the atmospheric air in urbanised zones (Millward and Sabir 2011).

The aim of the research conducted from 2013 to 2014 in selected parks and municipal forests of the city of Poznan was to determine the state of health of Tilia cordata Mill., Acer platanoides L. and Quercus robur L. trees and to compare their state of health depending on the location of research sites. The aim of the research was also to determine the environmental variables that may have the greatest influence on the state of health of the tree species under analysis. The study may give an answer to the question of which of the species under investigation is the most suitable for planting in urbanised areas.

\section{MATERIAL AND METHODS}

The research comprised the municipal forests of the city of Poznan, which fulfil isolative and recreational functions for the city and its inhabitants. The forests are located on the outskirts of the city, away from oppressive sources of pollution. The research also took selected non-historic public parks of the city of Poznan into account. These were the following municipal forests and of parks (Fig. 1).

Two of the parks listed above were established in former forts of the outer circle of Prussian fortifications from the second half of the $19^{\text {th }}$ century (the park between the Czecha Housing Estate and Rusa Housing Estate and Rev. Joseph Jasinski Park). Two other parks were established as a result of the transformation of former Evangelical cemeteries (Gorczynski Park and Gustaw Manitius Park).

Three of the most common species of trees in the green areas of the city of Poznan (Acer platanoides L., Tilia cordata Mill. and Quercus robur L.) were included in the research. Every specimen of the examined species growing in the parks was taken into account whereas only a representative number of specimens of the examined species growing in municipal forests was taken into account (the areas of both parks and municipal forests were comparable) (Tab. 1).

From 2013 to 2014, the tree species under investigation growing in the selected locations were inventoried in the summer. During the inventorial work the following characteristics were identified:

- the circumference of the trunk of each tree (measured at a height of $130 \mathrm{~cm}$ above the ground). As far as multi-trunk trees bifurcating beneath the height of $130 \mathrm{~cm}$ are concerned, each trunk was measured separately,

- the diameter of the crown of each tree (as far as trees with irregular crowns are concerned,

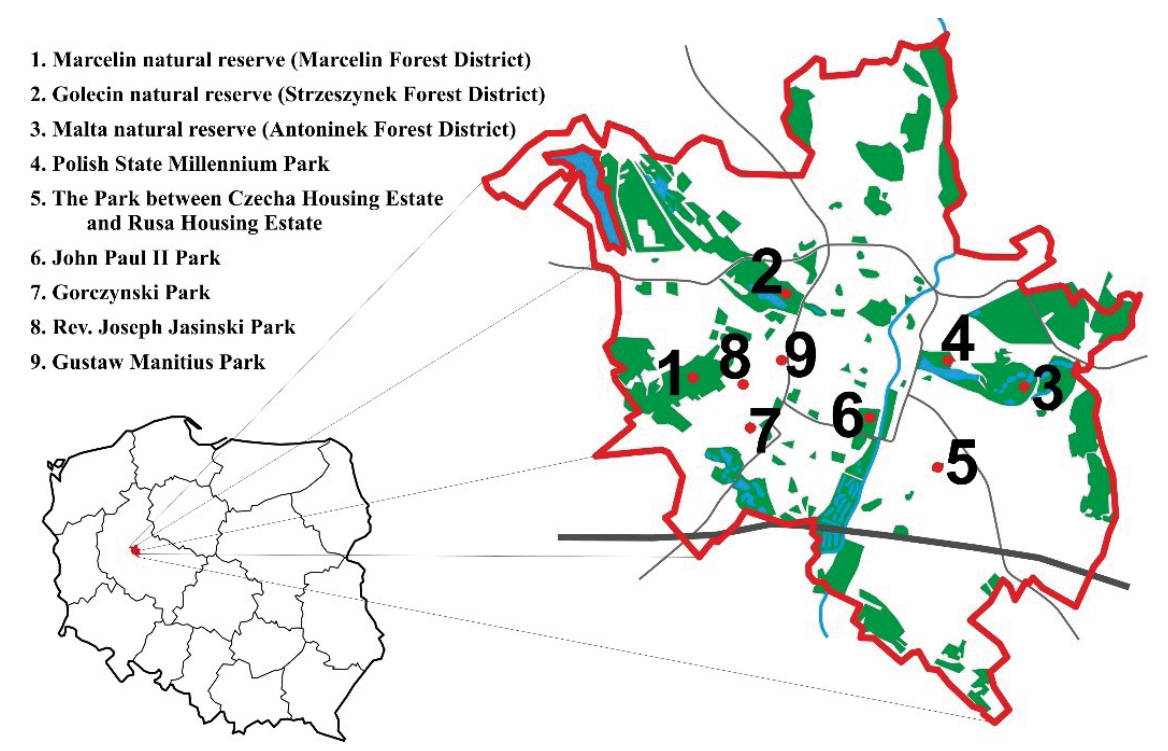

Figure 1. A map showing the location of the city of Poznan in Poland and the location of places under investigation 
Table 1. Total number of the examined specimens in different places of investigation and number of examined specimens of each of the examined species

\begin{tabular}{lcrrr}
\hline Place under investigation (growth condition) & $\begin{array}{l}\text { Total number } \\
\text { of specimens }\end{array}$ & Oak & Maple & Lime \\
\hline Marcelin natural reserve (trees growing close to one another) & 252 & 13 & 212 & 27 \\
Golecin natural reserve (trees growing close to one another) & 495 & 25 & 327 & 143 \\
Malta natural reserve (trees growing close to one another) & 370 & 22 & 247 & 101 \\
\hline Polish State Millennium Park (trees growing within park, on a lawn) & 218 & 30 & 173 & 15 \\
Park between Czecha Housing Estate and Rusa Housing Estate (trees growing & 197 & 11 & 168 & 18 \\
within park, on a lawn) & & 178 & 35 & 71 \\
John Paul II Park (trees growing within park, on a lawn) & 183 & 14 & 58 & 111 \\
Gorczynski Park (trees growing within park, on a lawn) & 85 & 12 & 67 & 6 \\
Rev. Joseph Jasinski Park (trees growing within park, on a lawn) & 129 & 38 & 71 & 20 \\
Gustaw Manitius Park (trees growing within park, on a lawn) & 2107 & 200 & 1394 & 513 \\
\hline Total & & & \\
\hline
\end{tabular}

two extreme diameters were measured and the mean value was calculated),

- the height of each tree,

- the health status of the trees under study the state of health was evaluated on the basis of the criteria assessing the condition of the tree, including condition of tree crown, trunk and roots (Kosmala 2009).

The tree species under investigation growing in the selected locations were inventoried from the summer of 2013 to the summer of 2014. During the inventorial work the state of health was evaluated on the basis of the criteria assessing the condition of the tree, including the condition of the tree crown, trunk and roots.

Kosmala's method (2009), a modification of Roloff's method, was used in order to evaluate the health status of the trees. It gives the possibility of assessing the condition of trees growing in urbanised areas that are exposed to anthropogenic factors. Kosmala's method evaluates health status on the basis of criteria including the condition of the tree crown, trunk and roots, given in points (Tab. 2). Each of those criterions was considered based on two characteristics, one of which relates to tree construction defects, and the other, to symptoms of infection or disease.

The health evaluation assessed both the crown structure (the degree of defoliation and the crown health condition) and structure and health status of the trunk (including rubbing bark, sapwood and cracks) as well. The method also includes an assessment of the state of the root system of a tree (butt end state and structural root status based on the observation of the soil). The results are calculated as the health condition of a tree (C) according to the formula: $C=C_{C}+C_{T}+C_{R}$, where $C_{C}-$ crown condition, $C_{T}-$ trunk condition, $C_{R}$ - roots condition.

The final stage of the assessment in the abovementioned method is to determine the phase of vitality, health status and health category of trees according to Table 3.

Statistical analyses and models were made on the basis of discriminant analysis. As a result we checked which variables might have an influence on the state of health of Acer platanoides L. trees in the parks and municipal forests of Poznan. Canonical variate analysis (CVA), which is a canonical variant of Fisher's linear discriminant analysis (LDA), was used to construct the model

Table 2. Points range for each of the criteria

\begin{tabular}{lll}
\hline Element of tree & \multicolumn{1}{c}{ Criteria } & Points \\
\hline \multirow{2}{*}{ 1. Tree crown } & 1.1. crown structure & $0-15$ \\
& 1.2. crown health condition & $0-15$ \\
\cline { 2 - 3 } 2. Tree trunk & 2.1. trunk structure & $0-15$ \\
& 2.2. trunk health condition & $0-15$ \\
\cline { 2 - 3 } 3. Tree roots & 3.1. base of the trunk and structural roots status & $0-24$ \\
\hline
\end{tabular}


Table 3. Phases of vitality, health condition and health category of the examined trees

\begin{tabular}{|c|c|c|c|}
\hline Points & $\begin{array}{l}\text { Health } \\
\text { condition }\end{array}$ & Vitality phase & $\begin{array}{c}\text { Health } \\
\text { category } \\
\text { of a tree [Q] }\end{array}$ \\
\hline $100-96$ & very good & expansion & I \\
\hline $95-76$ & good & phase & II \\
\hline $75-46$ & average & $\begin{array}{l}\text { reduction } \\
\text { phase }\end{array}$ & III \\
\hline $45-16$ & bad & $\begin{array}{l}\text { stagnation } \\
\text { phase }\end{array}$ & IV \\
\hline $15-0$ & very bad & $\begin{array}{l}\text { resignation } \\
\text { phase }\end{array}$ & $\mathrm{V}$ \\
\hline
\end{tabular}

(Lepš and Šmilauer 2003). The discriminant analysis compared the influence of different variables on the health status of tree specimens in the parks and forests. The following parameters were included into the analysis: the distance of the parks and forests from the city centre, the closeness of industrial areas, main thoroughfares, watercourses and water reservoirs, the fitting of the parks and forests within the system of urban open spaces, the emission of gases from the combustion of fossil fuels in households and the original use of the territories. A stepwise progression analysis was used to find which variables have the greatest influence on the health status of Tilia cordata Mill., Acer platanoides L. and Quercus robur L. trees in the parks and forests of Poznan. All variables were assessed. The model included the variables that most contributed to the discrimination of groups on the basis of $p$ and $\mathrm{F}$ values for the variable under analysis. The process was repeated until the $p$ value was greater than 0.05 for the variable under analysis. In order to determine the limit level of significance, a Monte Carlo permutation test was made (individually for each variable and then for the whole model). All comparisons, calculations and graphic elements were made by means of Canoco for Windows and Microsoft Excel spreadsheets. The following tools of Canoco for Windows were used: Canoco for Windows 4.5, CanoDraw for Windows and WCanoIMP.

\section{RESULTS}

Table 4 lists the dendrometric parameters and the health status of the trees under study in the parks and municipal forests of the city of Poznan. The table includes basic indexes describing the heterogeneous sets of figures (the minimum and maximum value, arithmetic mean and standard deviation). The trees growing in the forests were definitely in the best state of health. This may have been caused by the fact that they were better isolated from the factors of urbanisation. There was a negative dependence observed between the dendrometric parameters and the health status. When analysing Table 4, it is possible to observe a correlation concerning the dendrometric parameters. The specimens of all of the species inventoried in the forests were characterised by smaller crown sizes, smaller trunk circumferences and they were smaller than the specimens inventoried in the parks. This dependence may have been caused by greater tree density in the forests, which limited the growth of individual species.

The statistical analyses and models were based on discriminant analysis. As a result of the analyses we checked which variables might have an influence on the state of health of three tree species (Quercus robur L., Tilia cordata Mill. and Acer platanoides L.) in the urban open space in Poznan. Canonical variate analysis (CVA), which is a canonical variant

Table 4. The dendrometric parameters and the state of health of the trees under study in the parks and municipal forests of the city of Poznan [O - stem circumference, D - crown diameter, H - tree height, Q - health category]

\begin{tabular}{|c|c|c|c|c|c|c|c|c|c|c|c|c|c|}
\hline & & \multicolumn{4}{|c|}{ Quercus robur L. } & \multicolumn{4}{|c|}{ Acer platanoides L. } & \multicolumn{4}{|c|}{ Tilia cordata Mill. } \\
\hline & & $\begin{array}{c}\mathrm{H} \\
(\mathrm{m})\end{array}$ & $\begin{array}{c}\mathrm{O} \\
(\mathrm{cm})\end{array}$ & $\begin{array}{c}\mathrm{D} \\
(\mathrm{m})\end{array}$ & Q & $\begin{array}{c}\mathrm{H} \\
(\mathrm{m})\end{array}$ & $\begin{array}{c}\mathrm{O} \\
(\mathrm{cm})\end{array}$ & $\begin{array}{c}\mathrm{D} \\
(\mathrm{m})\end{array}$ & Q & $\begin{array}{c}\mathrm{H} \\
(\mathrm{m})\end{array}$ & $\begin{array}{c}\mathrm{O} \\
(\mathrm{cm})\end{array}$ & $\begin{array}{c}\mathrm{D} \\
(\mathrm{m})\end{array}$ & Q \\
\hline \multirow{4}{*}{ Forests } & $\min$ & 2.1 & 13 & 1.4 & 1 & 7 & 27 & 5 & 1 & 1.1 & 10 & 0.9 & 1 \\
\hline & $\max$ & 19 & 256 & 13 & 2 & 32 & 287 & 29.5 & 3 & 8.0 & 81 & 5.7 & 3 \\
\hline & $\bar{x}$ & 11.77 & 77.53 & 3.82 & 1.09 & 17.41 & 96.69 & 13.44 & 1.13 & 3.4 & 41.24 & 2.4 & 1.06 \\
\hline & SD & 3.91 & 52.11 & 2.07 & 0.23 & 2.39 & 29.84 & 2.11 & 0.50 & 1.47 & 17.14 & 1.41 & 0.29 \\
\hline \multirow{4}{*}{ Parks } & $\min$ & 2 & 13 & 1.7 & 1 & 2 & 6 & 1.6 & 1 & 2 & 10 & 1.5 & 1 \\
\hline & $\max$ & 33 & 304 & 27 & 5 & 31 & 268 & 47 & 5 & 24 & 233 & 20 & 5 \\
\hline & $\bar{x}$ & 17.56 & 157.48 & 12.4 & 1.64 & 17.45 & 97.56 & 9.21 & 1.51 & 16.54 & 155.22 & 10.41 & 1.94 \\
\hline & SD & 2.51 & 45.62 & 4.12 & 0.71 & 2.11 & 34.75 & 3.55 & 0.88 & 3.98 & 42.41 & 4.51 & 0.79 \\
\hline
\end{tabular}




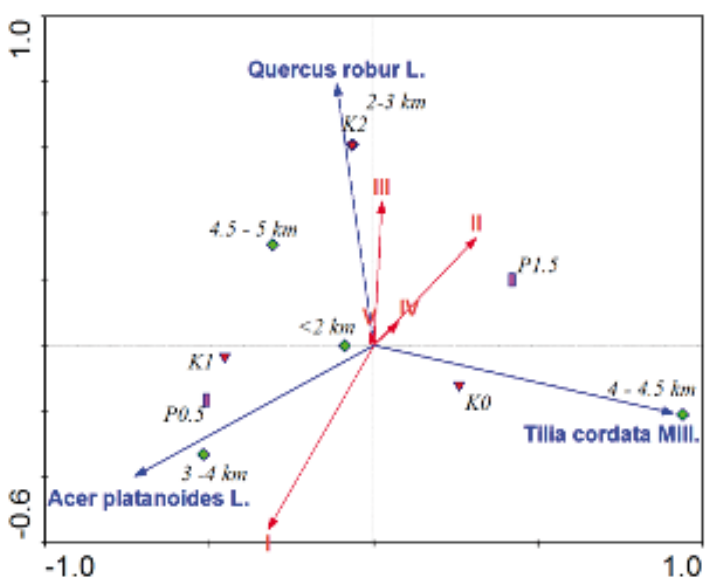

Figure 2. A CVA model $(n=2107)$ - the dependences between the state of health of the species under investigation growing in the forests and parks of the city of Poznan and the location of the parks and forests, the closeness of industrial areas, main thoroughfares, watercourses and water reservoirs [I-V - health category, $<2,2-3,3-4,4-4.5,4.5-5 \mathrm{~km}$ - the distance between the park and the city centre, $\mathrm{K} 0$ - no main thoroughfares, $\mathrm{K} 1$, $\mathrm{K} 2$ - one (two) main thoroughfares in the neighbourhood, $\mathrm{P} 0$ - no industrial areas, $\mathrm{P} 0.5, \mathrm{P} 1.5$ - industrial areas in the neighbourhood $<0.5<1.5 \mathrm{~km}](p<0.05)$

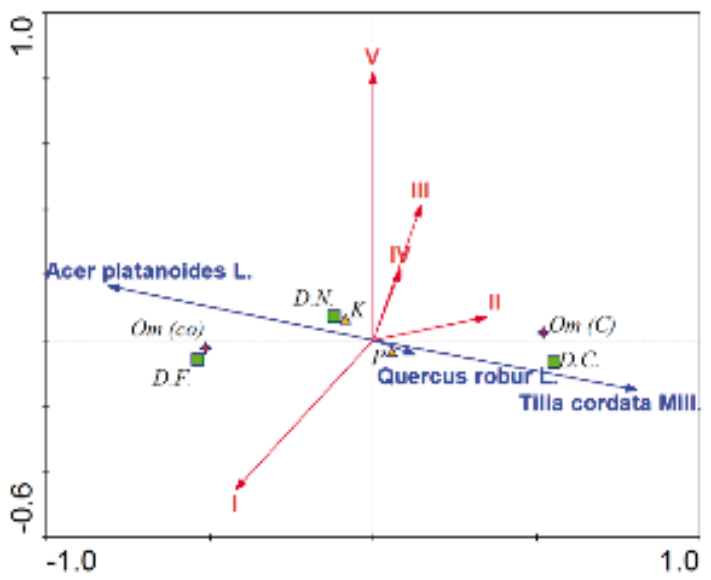

Figure 3. A CVA model $(\mathrm{n}=2107)$ - the dependences between the state of health of the species under investigation growing in the forests and parks of the city of Poznan and the original use of the areas where parks and forests were established, the method of heating in the buildings located in the areas adjacent to parks and forests and the fitting with the urban open space system [I-V - health category, D.N. - former wasteland, D.C. former cemeteries, D.F. - former forts, Om(co) - estates with central heating, $\mathrm{Om}(\mathrm{C})$ - estates heated with fossil fuels, $\mathrm{K}-$ parks and forests fitted with green wedges, $\mathrm{P}-$ parks and forests fitted with green rings] $(p<0.05)$

of Fisher's linear discriminant analysis (LDA), was used to construct the model.

The study used ordination techniques, which ordered the trials along the gradient represented both by the axis of ordinates and the axis of abscissas. In order to check which technique would be the most suitable for the dataset under analysis, the correspondence analysis (CA) was made. The procedure was supposed to answer the question about the character of the dataset under analysis on the basis of the gradient length (linear or unimodal) (Braak and Šmilauer 2002).

The correspondence analysis (CA) proved that the gradient length for the dataset under investigation was 4.51 (unimodal distribution). Therefore, it was possible to apply the following techniques of analyses: CCA, DCCA or hCCA. The last of the three techniques was selected. The hybrid CCA enables the introduction of three different types of variables into the model.

The state of health of the trees both in the parks and municipal forests of the city of Poznan largely depends on the environmental variables and the location of the urban open space. As results from the analysis below (Fig. 2), the specimens belonging to the first health class were located in the most distant areas from the centre, without industrial facilities or main thoroughfares. The presence of watercourses and water reservoirs in close proximity to green areas is an important factor determining the state of health of the trees. The Tilia cordata Mill. and Acer platanoides L. trees in the parks and forests with water reservoirs were absolutely the healthiest. The trees of the Quercus robur L. species growing in the areas located nearest to the centre and without a water reservoir were in the worst health class. The neighbourhood of main thoroughfares also had a negative influence on the quality of green areas in the city.

The method of heating buildings located in the areas adjacent to parks and forests has an indirect influence on the state of health of the species under investigation. The specimens growing in green areas where most of the estates were equipped with central heating were definitely in a better health class than the trees located near the estates heated with fossil fuels (Fig. 3). The trees of the Acer platanoides L. proved to be characteristic of the areas of former forts. Quercus robur L. trees were the most numerous in the former wasteland, whereas the largest number of Tilia cordata Mill. trees could be found in the areas of former cemeteries. As can be seen in the research, the systems of green areas also play a vital role in cities. Compact wedges of public green space are a buffer zone neutralising the anthropogenic effect. 


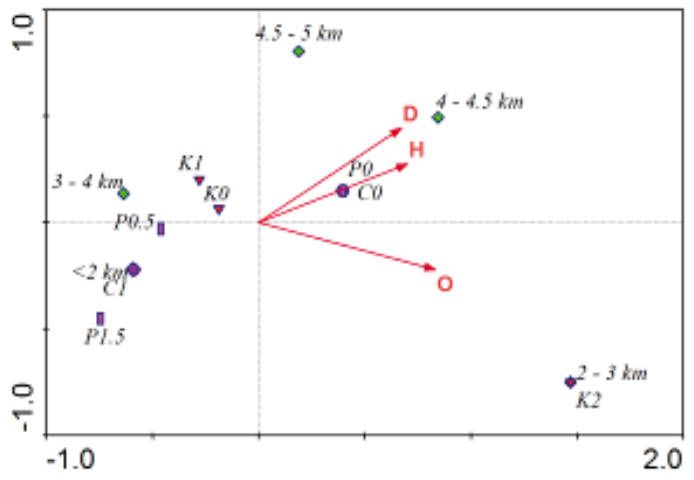

Figure 4. A CVA model $(n=2107)$ - a comparison of the dendrometric and environmental parameters $[<2,2-3$, $3-4,4-4.5,4.5-5 \mathrm{~km}$ - the distance between the park and the city centre [m], K0 - no main thoroughfares, K1, K2 - one (two) main thoroughfares in the neighbourhood, P0 - no industrial areas, P0.5, P1.5 - industrial areas in the neighbourhood $<0.5<1.5 \mathrm{~km}, \mathrm{C} 0-$ no watercourses or water reservoirs, $\mathrm{C} 1$ - watercourses or water reservoirs in the neighbourhood, $\mathrm{O}$ - stem circumference, D crown diameter, $\mathrm{H}$ - tree height, $\mathrm{Q}-$ health condition] $(p<0.05)$

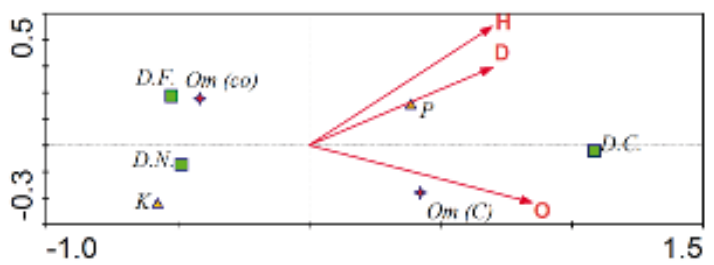

Figure 5. A CVA model $(n=2107)$ - a comparison of the dendrometric and geographic parameters of the species under investigation in parks and forests [D.N. - former wasteland, D.C. - former cemeteries, D.F. - former forts, $\mathrm{Om}(\mathrm{co})$ - estates with central heating, $\mathrm{Om}(\mathrm{C})$ - estates heated with fossil fuels, $\mathrm{K}$ - parks and forests fitted with green wedges, $\mathrm{P}$ - parks and forests fitted with green rings, $\mathrm{O}$ - stem circumference, $\mathrm{D}$ - crown diameter, $\mathrm{H}-$ tree height, $\mathrm{Q}-$ health condition] $(p<0.05)$

The trees growing in green wedges were definitely included in the best health class.

The two models below (Figs 4 and 5) compare the dendrometric parameters and both environmental and geographical parameters as well within the three species under study, growing in municipal forests and city parks. The height and crown width of the investigated tree species was highest among trees growing at a distance of $4-4.5 \mathrm{~km}$ from the city's centre while the biggest circumference of the trunk was observed among the trees growing at a distance of 2-3 km from the city's centre, close to the main thoroughfares. The lack of watercourses, water reservoirs and industrial areas in the neighbourhood as well was directly proportional to the height and the diameter of the crown of the examined trees. The circumference of the trunk parameter was positively correlated with the neighbourhood estates heated with fossil fuels.

\section{DISCUSSION}

All over the world there have been numerous studies on the influence of air pollution on the state of health of trees. They included assessments of the state of health of the specimens under investigation only in strictly defined locations, e.g. near motorways, main thoroughfares in cities or in urban open spaces (Mazzeo et al. 2005). However, there have been few studies on the vegetation and its state of health in urbanised areas - both in green areas and built-up areas. Such a complex approach to the research seems to be more appropriate and should provide a more complete answer to the question concerning the environmental threats to trees growing in different locations in urbanised areas (Cohen et al. 2014).

According to Zierl (2004), the degree of defoliation of tree crowns may be regarded as the best available criterion of the state of health of trees. However, the results of the research presented in this article show that it is more appropriate to include the following elements into the assessment of the state of health of trees to ensure its complexity: tree crown (the shape of the crown, damaged boughs and branches, degree of defoliation), trunk (disease symptoms, presence of wounds, cavities, cracks or bark stripping) and root zone (damage, disease symptoms, soil conditions in the root zone) (Kosmala 2009). The research conducted in Poznan between 2011 and 2013 proved that the state of health of three tree species under investigation chiefly depended on the following factors: the distance between the sites of growth of the trees under study, the closeness of main thoroughfares and the presence of water reservoirs. Those findings were confirmed by the results of earlier studies (Aasamaa and Sõber 2001, Saha et al. 2012).

Small-leaved lime trees growing in the municipal forests of Poznan were characterised by a better state of health than Norway maple or pedunculate oak trees, although the difference in the state of health between Acer platanoides L. and Quercus robur L. was not statistically significant. These findings were confirmed by studies that indicated that damage to Tilia cordata Mill. trees is definitely more frequent and visible if the trees 
grow in regions where the air is more polluted (Khavaninzadeh et al. 2014).

Acer platanoides L. trees are often listed as a species planted in cities due to their resistance to conditions and pollution in urbanised areas (Bojarczuk 1999). The research conducted between 2011 and 2013 confirmed this observation, but it also proved that Norway maple trees growing in municipal forests were more resistant to urban conditions than specimens of the same tree species growing in parks.

The specimens of Acer platanoides L. trees growing in municipal forests and green wedges of Poznan were characterised by the best state of health. This may have been caused by their better resistance to anthropopressure due to the larger area of forests and, in consequence, due to better buffering properties. Municipal forests in large urban agglomerations play a particularly important role in the biological regulation of pollution. Acer platanoides $\mathrm{L}$. trees are characterised by a better state of health than Quercus robur L. trees growing in public green spaces in the city of Poznan (Krzyżaniak et al. 2013). According to data from reference publications, older specimens of Norway maple trees are more resistant to the stress caused by abiotic factors (Millward and Sabir 2011). However, these observations were not confirmed by the data collected in the research conducted in Poznan between 2011 and 2013. Acer platanoides L. trees, aged 40-70 years, growing both in municipal forests and in the non-historic parks of Poznan were found to be in the best health. The research led to the conclusion that Tilia cordata Mill. and Quercus robur L. trees may be used as biological indicators of the state of environmental pollution in urbanised areas. According to the data provided in reference publications, small-leaved lime trees are better suited for this purpose than silver lime trees, which have hairier leaves (Khavaninzadeh et al. 2014). However, other studies suggest that it is the lime trees with hairier leaves that are better suited as biological indicators of air pollution in urbanised areas (Kardel et al. 2011). Aesculus hippocastanum L. trees may be more useful than small-leaved lime trees for the biological monitoring of air pollution with lead and copper compounds (Aničić et al. 2011). There are divergent data concerning pedunculate oak trees. Kardel et al. (2011) report that these trees may be used as biological indicators in urbanised areas, whereas Aboal et al. (2004) prove that Quercus robur L. trees should not be used for biological monitoring in minimally polluted areas.
For those reasons it seems that it is justified to conduct further research that could solve all of the aforementioned conflicting issues.

\section{CONCLUSIONS}

1. The state of health of the species under study growing in cities is determined by anthropogenic factors. The following factors have the most negative influence on the state of health of oak, maple and lime trees: closeness to the city centre, main thoroughfares and estates heated with fossil fuels.

2. Acer platanoides L. was the tree species representing the best state of health in parks, whereas Tilia cordata Mill. was the species representing the best state of health in forests.

3. The research led to the conclusion that among the three species under study, Acer platanoides L. seems to be the most appropriate for city parks.

\section{ACKNOWLEDGEMENTS}

This study was financially supported with grants No. 507.655.54 and No. 507.655.55, founded by The Ministry of Science and Higher Education of The Republic of Poland.

\section{REFERENCES}

AasamaA K., Sõber A., 2001. Hydraulic conductance and stomatal sensitivity to changes of leaf water status in six deciduous tree species. Biol. Plantarum 44(1): 65-73.

Aboal J.R., Fernández J.A., CArballeira A., 2004. Oak leaves and pine needles as biomonitors of airborne trace elements pollution. Environ. Exp. Bot. 51(3): 215-225.

Aničić M., Spasić T., Tomašević M., Rajšić S., Tasić M., 2011. Trace elements accumulation and temporal trends in leaves of urban deciduous trees (Aesculus hippocastanum and Tilia spp.). Ecol. Indic. 11(3): 824-830.

Barzdajn W., 2006. Dęby (Oak Trees). Wydawnictwo Naukowe PWN, Warszawa (Warsaw).

Bassuk N., Deanna F.C., Marranca B.Z., Barb N., 2009. Recommended urban trees: site assessment and tree selection for stress tolerance. Ithaca, New York: Urban Horticulture Institute, Cornell University.

Baumgardner D., Varela S., Escobedo F.J., Chacalo A., Оснол C., 2012. The role of a peri-urban forest on air quality improvement in the Mexico City megalopolis. Environ. Pollut. 163: 174-183.

BojarczuK K., 1999. Klony: (Maple Trees) [Acer campestre L., Acer platanoides L., Acer pseudoplatanus L.]. Bogucki Wydawnictwo Naukowe S.C., Poznań. 
BorATYNSKi A., 1999. Systematyka i geograficzne rozmieszczenie (The Taxonomy and Geographical Distribution). In: Klony: (Maple Trees) [Acer campestre L., Acer platanoides L., Acer pseudoplatanus L.]. K. Bojarczuk (ed.), Bogucki Wydawnictwo Naukowe S.C., Poznań: 14-74.

BraAk C.J.F., Šmilauer P., 2002. CANOCO Reference Manual and CanoDraw for Windows User's Guide: Software for Canonical Community Ordination (version 4.5). Biometris.

Cekstere G., Osvalde A., 2013. A study of chemical characteristics of soil in relation to street trees status in Riga (Latvia). Urban For. Urban Gree. 12(1): 69-78.

Cohen P., Potchter O., Schnell I., 2014. A methodological approach to the environmental quantitative assessment of urban parks. Appl. Geogr. 48: 87-101.

EichHorn J., PaAr U., 2000. Oak decline in Europe. Methods and results of assessments in the ICP forests. In: Recent advances on oak health in Europe. T. Oszako and C. Dalatour (eds), IBL-Warszawa, Warszawa: 41-52.

Honour S.L., Bell J.N.B., Ashenden T.W., Cape J.N., Power S.A., 2009. Responses of herbaceous plants to urban air pollution: Effects on growth, phenology and leaf surface characteristics. Environ. Pollut. 157(4): 1279-1286.

Hovmand M.F., Nielsen S.P., Johnsen I., 2009. Root uptake of lead by Norway spruce grown on $210 \mathrm{~Pb}$ spiked soils. Environ. Pollut. 157(2): 404-409.

Kanakidou M., Mihalopoulos N., Kindap T., Im U., Vrekoussis M., Gerasopoulos E. et al., 2011. Megacities as hot spots of air pollution in the East Mediterranean. Atmos. Environ. 45(6): 1223-1235.

Kardel F., Wuyts K., Maher B.A., Hansard R., SAmson R., 2011. Leaf saturation isothermal remanent magnetization (SIRM) as a proxy for particulate matter monitoring: Inter-species differences and inseason variation. Atmos. Environ. 45(29): 5164-5171.

Khavaninzadeh A.R., Veroustraete F., Buytaert J.A. N., SAmson R., 2014. Leaf injury symptoms of Tilia sp. as an indicator of urban habitat quality. Ecol. Indic. 41: 58-64.

Kosmala M., 2009. Metoda oceny kondycji drzew z uwzględnieniem bezpieczeństwa i uszkodzeń mechanicznych (A method of assessment of the condition of trees including safety and mechanical damage). Instytut Gospodarki Przestrzennej i Mieszkalnictwa, Warszawa.

KrzyżaniaK M., Świerk D., UrbańSki P., Walerzak M.T., 2013. Evaluation of the effect of environmental variables on health condition of Quercus robur L. in parks. Ecol. Chem. Eng. S 20(4): 689-700.

LePš J., Šmilauer P., 2003. Multivariate Analysis of Ecological Data using CANOCO. Cambridge University Press, Cambridge.

Mazzeo N.A., Venegas L.E., Choren H., 2005. Analysis of $\mathrm{NO}, \mathrm{NO}_{2}, \mathrm{O}_{3}$ and $\mathrm{NO}_{\mathrm{x}}$ concentrations measured at a green area of Buenos Aires City during wintertime. Atmos. Environ. 39(17): 3055-3068.

Mertens J., Van Nevel L., De Schrijver A., Piesschaert F., Oosterbanan A., Tack F.M.G., et al., 2007. Tree species effect on the redistribution of soil metals. Environ. Pollut. 149(2): 173-181.

Millward A.A., Sabir S., 2011. Benefits of a forested urban park: What is the value of Allan Gardens to the city of Toronto, Canada? Landscape Urban Plan. 100(3): 177-188.

Novak K., Skelly J.M., Schaub M., Kräuchi N., Hug C., Landolt W., et al., 2003. Ozone air pollution and foliar injury development on native plants of Switzerland. Environ. Pollut. 125(1): 41-52.

Paoletti E., Bardelli T., Giovannini G., Pecchioli L., 2011. Air quality impact of an urban park over time. Procedia Environ. Sci. 4: 10-16.

Roloff A., Korn S., Gillner S., 2009. The ClimateSpecies-Matrix to select tree species for urban habitats considering climate change. Urban For. Urban Gree. 8(4): 295-308.

Saha S., Kuehne C., Kohnle U., Brang P., Ehring A., GeIsEL J., et al., 2012. Growth and quality of young oaks (Quercus robur and Quercus petraea) grown in cluster plantings in central Europe: A weighted meta-analysis. Forest Ecol. Manag. 283: 106-118.

Schnell I., Potchter O., Yaakov Y., Epstein Y., Brener S., Hermesh H., 2012. Urban daily life routines and human exposure to environmental discomfort. Environ. Monit. Assess. 184(7): 4575-4590.

Sıöman H., Busse N.A., 2010. Selecting trees for urban paved sites in Scandinavia - A review of information on stress tolerance and its relation to the requirements of tree planners. Urban For. Urban Gree. 9(4): 281293.

Sonesson K., 1999. Oak Decline in Southern Sweden. Scand. J. Forest Res. 14(4): 368-375.

ZierL B., 2004. A simulation study to analyse the relations between crown condition and drought in Switzerland. Forest Ecol. Manag. 188(1-3): 25-38.

Received November 3, 2014; accepted April 14, 2015 